CLINICAL STUDY

\title{
Stimulating effect of growth hormone on cytokine release in children
}

\author{
Mauro Bozzola, Fabrizio De Benedetti ${ }^{1}$, Mara De Amici, Béatrice Jouret ${ }^{2}$, Paola Travaglino, Sara Pagani, \\ Françoise Conte ${ }^{2}$ and Maïthé Tauber ${ }^{2}$ \\ Dipartimento di Scienze Pediatriche, Università degli Studi di Pavia, IRCCS San Matteo, Piazzale le Golgi 2, 27100 Pavia, Italia, ${ }^{1}$ Direzione Scientifica, \\ IRCCS Ospedale Pediatrico Bambino Gesù, Piazza S. Onofrio 4, O0165 Roma, Italia and ${ }^{2}$ Unité d'Endocrinologie, Hôpital des Enfants, Toulouse, France \\ (Correspondence should be addressed to M Bozzola; Email: m.bozzola@smatteo.pvit)
}

\begin{abstract}
Objective: The aim of the present study was to investigate the effect of exogenously administered GH on serum levels of interleukin (IL)-1 $\beta$, IL-2, IL-12, tumor necrosis factor (TNF)- $\alpha$ and interferon (IFN)- $\gamma$ and their relation with IGF-I levels in normal short stature children.

Design and methods: 23 short prepubertal non GH-deficient children (10 females and 13 males) whose mean \pm S.D. chronological age was $11.95 \pm 1.85$ years (from 8.80 to 14.89 years), and mean \pm S.D. bone age was $10.48 \pm 2.44$ years, were evaluated during a somatomedin generation test (human GH $0.1 \mathrm{IU} / \mathrm{kg}$ per day for 4 days) to exclude a partial GH resistance as the cause of short stature; 34 sex- and age-matched healthy subjects were studied as controls. Circulating cytokine values were measured in basal conditions in all children, and $12 \mathrm{~h}$ following the 4 th GH subcutaneous injection in the 23 short children only.

Results: No significant differences were found between short children and controls in basal values of serum IGF-I (192.1 \pm 18.3 and $198.2 \pm 28.2 \mathrm{ng} / \mathrm{ml}$ respectively). In short subjects there was a significant increase in serum IGF-I levels after the 4th GH injection (from 192.1 $18.3 \mathrm{ng} / \mathrm{ml}$, i.e. $-1.16 \pm 0.16$ standard deviation score (SDS) to $338.2 \pm 27.1 \mathrm{ng} / \mathrm{ml}$, i.e. $0.14 \pm 0.17$; $P<0.00001)$. No significant differences were found between short children and controls in basal concentrations of serum INF- $\gamma(19 \pm 4$ and $26 \pm 5 \mathrm{mIU} / \mathrm{ml}$ respectively), IL- $1 \alpha(24.950 \pm 3.613$ and $20.896 \pm 2.778 \mathrm{pg} / \mathrm{ml}$ respectively), IL-2 (3.945 \pm 1.209 and $4.794 \pm 0.562 \mathrm{pg} / \mathrm{ml}$ respectively), IL$12(1.093 \pm 0.269$ and $1.976 \pm 0.596 \mathrm{pg} / \mathrm{ml}$ respectively), and TNF- $\alpha$ (1.794 \pm 0.559 and $2.188 \pm 0.346 \mathrm{pg} / \mathrm{ml}$ respectively). Likewise, a significant increase was found in serum INF- $\gamma$ (before $19 \pm 4$ and after four $\mathrm{GH}$ injections $185 \pm 57 \mathrm{mIU} / \mathrm{ml}$ respectively; $P<0.008$ ), IL-1 $\beta$ $(24.950 \pm 3.613$ to $43.339 \pm 5.431 \mathrm{pg} / \mathrm{ml}$ respectively; $P<0.0001)$, IL-2 $(3.945 \pm 1.209$ to $9.165 \pm 2.331 \mathrm{pg} / \mathrm{ml}$ respectively; $P<0.003)$, IL-12 (1.093 \pm 0.269 to $3.724 \pm 0.637 \mathrm{pg} / \mathrm{ml} \mathrm{respect-}$ ively; $P<0.0007)$ and TNF- $\alpha(1.794 \pm 0.559$ to $9.266 \pm 3.066 \mathrm{pg} / \mathrm{ml}$ respectively; $P<0.01)$.

Conclusions: Cytokine release can be affected by short-term GH administration in normal children indicating a direct influence of $\mathrm{GH}$ on the immune system.
\end{abstract}

European Journal of Endocrinology 149 397-401

\section{Introduction}

A vast body of evidence points to the existence of a bidirectional relationship between the endocrine system and immune function. Specifically, concerning the growth hormone $(\mathrm{GH}) /$ insulin-like growth factor-I (IGF-I) system, the presence of such a bidirectional influence with cytokines, the soluble factors released by immune cells, has been shown by several studies. The proinflammatory cytokines tumor necrosis factor (TNF), interleukin (IL)-1 and IL-6 have been shown to affect the GH/IGF-I system at several levels with relevant in vivo consequences in human diseases (1-6). Conversely, GH not only regulates growth but can also control the immune function. In particular, GH has been demonstrated to play a role in priming macrophages for the release of cytokines such as IL- $1 \beta$, IL- 6 and TNF- $\alpha$ which are involved in the acute phase immune response (7) and to induce interferon- $\gamma$ (IFN- $\gamma$ ) production by T lymphocytes (8). In vitro experiments indicate that the action of $\mathrm{GH}$ on immune cells and cytokine production appears to be mediated by IGF-I (9-11). However, to the best of our knowledge no in vivo data are available indicating a direct relationship between the effect of GH on IGF-I levels and cytokine levels.

The aim of the present study was to investigate the effect of exogenously administered $\mathrm{GH}$ on serum levels of IL- $1 \beta$, IL- 2 , IL-12, TNF- $\alpha$ and IFN- $\gamma$ and their relation with IGF-I levels in normal short stature children. 


\section{Patients and methods}

\section{Patients and study design}

The study population consisted of 23 short prepubertal children (10 females and 13 males), whose mean \pm S.D. chronological age was $11.95 \pm 1.85$ years (from 8.80 to 14.89 years), mean \pm S.D. bone age was $10.48 \pm 2.44$ years, height was $-2.54 \pm 0.16$ standard deviation score (SDS), and body mass index was $-0.503 \pm 0.20$ SDS. The GH response after classical pharmacological stimuli was normal in all children with serum peak levels of $17.21 \pm 0.99 \mathrm{ng} / \mathrm{ml}$. No patient suffered from GH deficiency or other endocrine deficiencies or chronic diseases or had chromosomal abnormalities or dysmorphic syndromes. Extra blood obtained during a somatomedin generation test used to evaluate $\mathrm{GH}$ resistance as the cause of short stature, was used for cytokine measurement. Thirty-four healthy subjects comparable for age and sex, who were taking part in a screening program for hyperlipidemia at school, were studied as controls. Informed consent was obtained from the parents of all children.

Blood samples were collected from patients and controls between $0800 \mathrm{~h}$ and $0900 \mathrm{~h}$ before and $12 \mathrm{~h}$ after the fourth GH subcutaneous injection $(0.1 \mathrm{IU} / \mathrm{kg}$ per day). Blood samples were placed on ice immediately and centrifuged within $1 \mathrm{~h}$. Placebo was not given to either short or control children because the local ethical committee did not approve a double blinded or placebo controlled study. Sera were stored at $-20^{\circ} \mathrm{C}$ until assay.

\section{Measurement of cytokine levels}

Serum cytokine concentrations were measured by an IRMA based on coated-tube separation and on the oligoclonal system using several monoclonal antibodies directed against distinct cytokine epitopes. Serum IFN- $\gamma$ levels were evaluated by immunoenzyme assay (Immunotech-Marseille, France); serum IL-1 $\beta$ values were evaluated by a two-step sandwich enzyme immunoassay (Immunotech-Marseille); serum IL-2 concentrations were evaluated using a sandwich enzyme immunoassay (Immunotech-Marseille); serum IL-12 levels were evaluated by an immunoenzyme assay (Immunotech-Marseille) and TNF- $\alpha$ values were evaluated using a sandwich enzyme immunoassay (Immunotech-Marseille). No cross-reaction with the other cytokines was observed. We tested the sensitivity of the IL-12 assay as the concentration corresponding to the mean plus 2 S.D. of 20 replicates of zero standard and we found: $<3 \mathrm{pg} / \mathrm{ml} \mathrm{IL-12}$ and $<5 \mathrm{pg} / \mathrm{ml} \mathrm{TNF}$, IL-1, and IL-2. The intra- and interassay coefficients of variation were between $2.2 \%$ and $12.6 \%$, and between $6.6 \%$ and $12.2 \%$ respectively for INF- $\gamma$; between $6 \%$ and $20 \%$, and between $4.4 \%$ and $11.5 \%$ respectively for IL- $1 \alpha$; between $2.8 \%$ and $3.4 \%$, and between $2.4 \%$ and $10.1 \%$ respectively for IL-2; between
$1.8 \%$ and $4.9 \%$, and $4.1 \%$ and $9.5 \%$ respectively for IL12 ; and between $5.4 \%$ and $12.8 \%$, and $1.6 \%$ and $10 \%$ respectively for TNF- $\alpha$.

\section{Measurement of IGF-I levels}

Serum IGF-I concentrations were measured by doubleantibody RIA using immunochemicals and tracer provided by Medgenix (Fleurus, Belgium). The sensitivity of the assay was $150 \mathrm{pg} / \mathrm{ml}$; the intra- and interassay coefficients of variation were 6 and $7.5 \%$ respectively. In order to avoid interference from binding proteins, single plasma EDTA samples taken from each patient were treated with acid-ethanol. Results are expressed as means \pm S.E.M.

\section{Statistical analysis}

Data were analyzed using the statistical analysis software package Statistica 5.0 (StatSoft Inc., Tulsa, OK, USA). Descriptive statistics were calculated and reported in terms of medians, minimum (min) and maximum (max) values. The Mann-Whitney U test for unpaired samples was used to compare cytokine levels between short stature children and controls. The non-parametric Wilcoxon test for paired samples was used to compare cytokine levels before and after GH administration. Correlations were analyzed using the Spearman rank correlation test. A $P$ value $<0.05$ was deemed statistically significant.

\section{Results}

No significant differences were found between short children and controls in basal values of serum IGF-I $(192.1 \pm 18.3$ and $198.2 \pm 28.2 \mathrm{ng} / \mathrm{ml}$ respectively). In short subjects there was a significant increase in serum IGF-I levels $(192.1 \pm 18.3 \mathrm{ng} / \mathrm{ml}$, i.e. $-1.16 \pm$ 0.16 SDS) after the fourth GH injection (338.2 \pm $27.1 \mathrm{ng} / \mathrm{ml}$, i.e. $0.14 \pm 0.17 ; P<0.00001$ by Wilcoxon test for paired samples). No significant differences were found between short children and controls in basal concentrations of serum IL-1 $\beta$, IL-2, IL-12 IFN- $\gamma$, and TNF- $\alpha$ (Table 1). When we compared cytokine levels

Table 1 Serum levels of the indicated cytokines in basal samples from short stature children and in healthy controls. Data are shown as median (min-max). The significance levels $(P)$ of the differences between short stature children and healthy controls are shown.

\begin{tabular}{lccc}
\hline Cytokine & Short stature children & Healthy children & $\boldsymbol{P}$ \\
\hline $\mathrm{IL}-1 \beta(\mathrm{pg} / \mathrm{ml})$ & $19.0(5.5-58.6)$ & $15.6(11.0-55.4)$ & 0.83 \\
$\mathrm{IL}-2(\mathrm{pg} / \mathrm{ml})$ & $3.3(0.4-13.5)$ & $4.4(1.2-9.8)$ & 0.35 \\
$\mathrm{IL}-12(\mathrm{pg} / \mathrm{ml})$ & $0.8(0.4-2.8)$ & $3.0(0-9.1)$ & 0.10 \\
IFN- $\gamma(\mathrm{mlU} / \mathrm{ml}$ & $20(0-60)$ & $30(4-50)$ & 0.40 \\
TNF- $\alpha(\mathrm{pg} / \mathrm{ml})$ & $0.9(0-6.1)$ & $2.2(0.6-5.2)$ & 0.25
\end{tabular}


before and after the fourth GH injection, we found, compared with basal levels, a significant increase in the concentrations of IL- $1 \beta$ (median: $38.0 \mathrm{pg} / \mathrm{ml}$; $\mathrm{min}-$ max: 12.9-92.2; $P=0.00004$ versus basal values by
Wilcoxon test for paired samples), IL-2 (median: $6.9 \mathrm{pg} / \mathrm{ml}$; $\min -\max : 3.5-28.6 ; P=0.006), \quad \mathrm{IL}-12$ (median: $3.2 \mathrm{pg} / \mathrm{ml}$; $\min -\max : 0.8-4.3 ; P=0.008$ ), IFN- $\gamma$ (median: $150 \mathrm{mIU} / \mathrm{ml}$; $\min -$ max: 20-710;
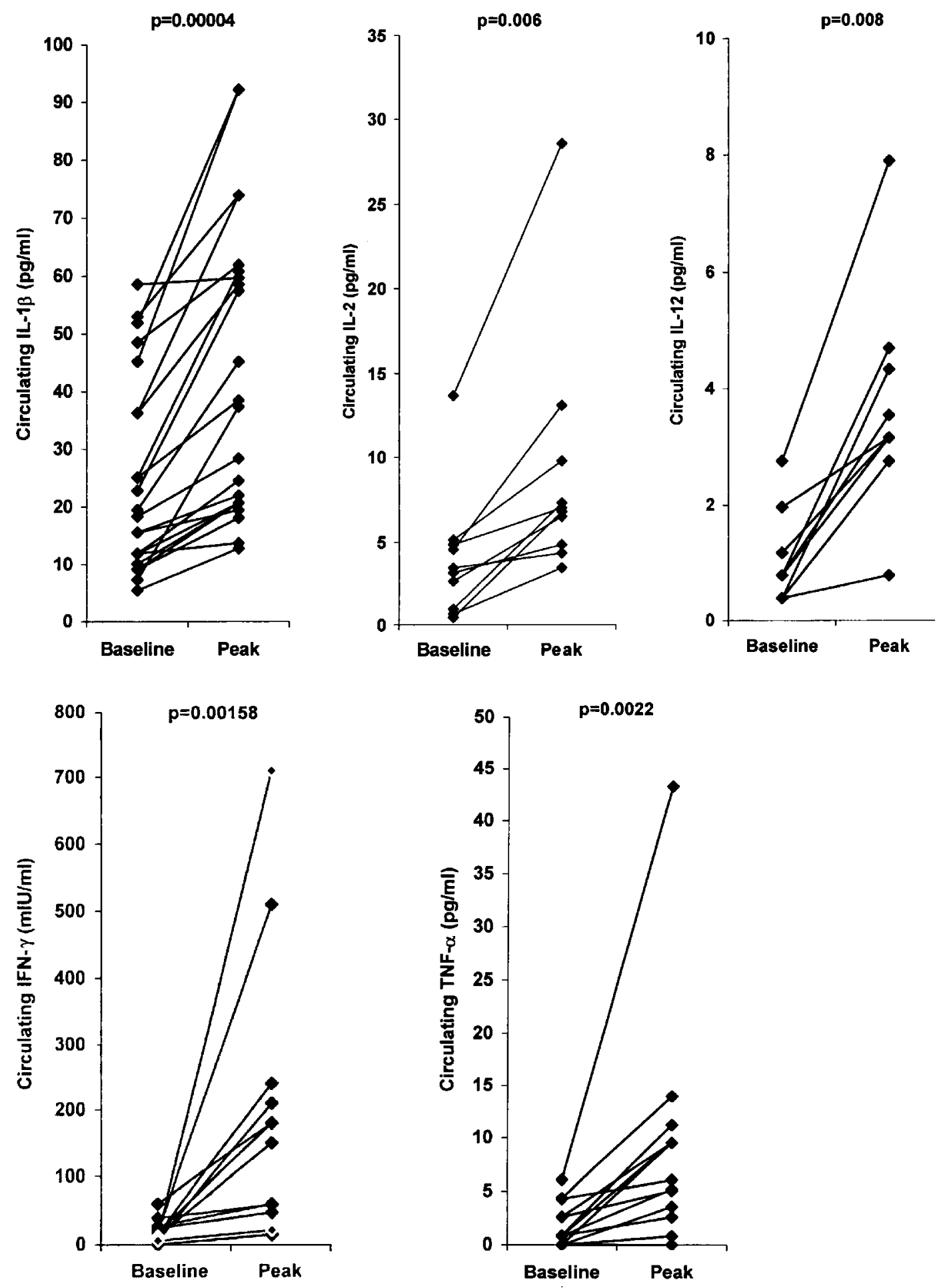

Figure 1 Circulating levels of IL-1 $\beta$, IL-2, IL-12, IFN- $\gamma$ and TNF- $\alpha$ in basal samples (baseline) and after the fourth GH injection (peak) in short stature children. 
$P=0.0015)$, and TNF- $\alpha$ (median: $6.1 \mathrm{pg} / \mathrm{ml}$; $\min -\max$ : 0.0-43.4; $P=0.0022$ ) (Fig. 1).

We found no significant correlations between serum IGF-I values and IL- $1 \beta$, IL- 2 , IL-12, IFN- $\gamma$ and TNF- $\alpha$ levels.

\section{Discussion}

A number of experimental findings in animals supports the hypothesis of an effect of $\mathrm{GH}$ over the humoral response (12). The dwarf Snell mouse having both a congenital hypopituitarism and thymus-dependent immunodeficiency normalizes the immune function after GH treatment (12). Unlike experimental data in animals, no difference in basal serum TNF- $\alpha$ and IL$1 \alpha$ concentrations between 15 children with $\mathrm{GH}$ deficiency and 19 controls was observed (13). The effect of $\mathrm{GH}$ or $\mathrm{GH}$-dependent factors on peripheral macrophages is confirmed by the significant increase in both serum TNF- $\alpha$ and IL-1 $\beta$ concentrations observed after $\mathrm{GH}$ injection, and by their fall $24 \mathrm{~h}$ later when serum GH values fell (13). Studies on GHdeficient children showed that the production of IL- $1 \alpha$ and IL-2 by mononuclear cells requires GH. In particular, IL-1 $\alpha$ production was normalized after 15 days of substitutive GH therapy and IL-2 after 3 months of treatment (14). The clinical significance of the relationship between GH and cytokine production in humans is debatable as no clinical signs of immune dysfunction have been observed even in patients with severe $\mathrm{GH}$ deficiency.

The pituitary gland is needed for the synthesis of TNF- $\alpha$ by macrophages. Hypophysectomized rats had markedly depressed macrophage synthesis of TNF- $\alpha$; exogenous GH partially reversed the effect of hypophysectomy (7). In contrast, in GH-deficient adults, basal TNF- $\alpha$ levels are high and fall after prolonged GH administration (15). On the other hand, no significant differences in basal TNF- $\alpha$ levels were reported between $\mathrm{GH}$ and idiopathic short stature children, and agematched controls (16).

We observed a great variability in basal cytokine levels, mainly IL-1 $\beta$, that increase after GH administration in different ways. In fact, in some children a clear elevation from basal values can be observed, while in other subjects no changes can be found.

The main result of our study is the clear influence of human $\mathrm{GH}$ administration on the cytokine secretion in children with normal GH production. This finding may reflect an effect on the immune system. Indeed IL-2, IFN- $\gamma$ and IL-12 are produced exclusively by cells of the immune system (i.e. T lymphocytes, and monocytes/macrophages and dendritic cells respectively). On the other hand, the increased levels of IL-1 $\beta$ and TNF- $\alpha$ may also be secondary to an effect of GH on other tissues, such as on endothelium, liver and fat tissue. Our results suggest a generalized effect of GH administration on cytokine secretion in vivo. This finding appears to be in keeping with the previously mentioned effect of $\mathrm{GH}$ on cytokine production by $\mathrm{T}$ lymphocytes and macrophages in experimental animals. However, it should be pointed out that the levels of IFN- $\gamma$, TNF- $\alpha$ and IL-1 $\beta$ found in children receiving $\mathrm{GH}$ were markedly lower than those found in patients with juvenile idiopathic arthritis or with pneumonitis (not shown). Therefore, at least for these three inflammatory cytokines, circulating levels associated with overt pathological inflammatory conditions were not attained. The effect could be mediated by GH-dependent factors such as IGF-I. However, we found no significant correlations between serum IGF-I values and each cytokine studied. Cells of the immune system, such as $\mathrm{T}$ and $\mathrm{B}$ lymphocytes and macrophages, express functional IGF-I receptors (17, 18). Moreover, since IGF-I is produced by immune cells (19), its effects on immune responses may be secondary to autocrine or paracrine mechanisms.

Several studies demonstrate that IGF-I, either endogenously produced or exogenously added, affects in vitro immune cell replication and function. IGF-I stimulates the proliferation of T cells (20) and mediates the growth promoting effect of $\mathrm{GH}$ on T-lymphoblastoid cell lines (10). In addition, it increases mitogen-induced IL-2 production (11), which might be responsible for the effect on proliferation. The in vivo relevance of these in vitro results has yet to be demonstrated. To the best of our knowledge a few observations suggest, albeit indirectly, an in vivo effect of $\mathrm{GH}$ on immune function in humans.

\section{References}

1 Barreca A, Ketelslegers JM, Arvigo M, Minuto F \& Thissen JP. Decreased acid-labile subunit (ALS) levels by endotoxin in vivo and by interleukin-1 $\beta$ in vitro. Growth Hormone IGF Research $19988217-223$.

2 De Benedetti F, Alonzi T, Moretta A, Lazzaro D, Costa P, Poli V, Martini A, Ciliberto G \& Fattori E. IL-6 causes growth impairment through a decrease in insulin-like growth factor-I: a model for stunted growth in children with chronic inflammation. Journal of Clinical Investigation $199799643-650$.

3 Fan J, Char D, Bagby GJ, Gelato MC \& Lang CH. Regulation of insulin-like growth factor-I (IGF-I) and IGF-binding proteins by tumor necrosis factor. American Journal of Physiology 1995269 R1204-R1212.

4 Fan J, Wojnar MM, Theodorakis M \& Lang CH. Regulation of insulin-like growth factor (IGF)-I mRNA and peptide and IGF-binding proteins by interleukin-1. American Journal of Physiology 1996 270 R621-R629.

5 Wolf M, Bohm S, Brand M \& Kreyman G. Proinflammatory cytokines interleukin-1 $\beta$ and tumor necrosis factor- $\alpha$ inhibit growth hormone stimulation of insulin-like growth factor-I synthesis and growth hormone receptor mRNA levels in cultured rat liver cells. European Journal of Endocrinology $1996135729-735$.

6 Bernton EW, Beach JE, Holaday JW, Smallridge RC \& Flein HG. Release of multiple hormones by a direct action of interleukin-1 on pituitary cells. Science $1987 \mathbf{2 3 8} 519-521$.

7 Edwards CK, Lorence RM, Dunham DM, Arkins S, Yunger LM, Greager JA et al. Hypophysectomy inhibits the synthesis of 
tumor necrosis factor- $\alpha$ by rat macrophages: partial restoration by exogenous growth hormone or interferon- $\gamma$. Endocrinology $1998128989-996$.

8 Mustafa A, Nyberg F, Mustafa M, Bakhiet M, Mustafa E, Winblad B et al. Growth hormone stimulates production of interferon- $\gamma$ by human peripheral mononuclear cells. Hormone Research 1997 $4811-15$

9 Reiner G, Clement I, Desfaits AC \& Lambert A. Direct stimulatory effect of insulin-like growth factor-I on monocyte and macrophage tumor necrosis factor alpha production. Endocrinology $19961374611-4618$.

10 Geffner ME, Bersh N, Lippe BM, Rosenfeld RG, Hintz RL \& Golde DW. Growth hormone mediates the growth of T lymphocytes cell lines via locally generated insulin-like growth factor I. Journal of Clinical Endocrinology and Metabolism $1990 \mathbf{7 1}$ 464-469.

11 Koojiman R, Rijkers GT \& Zegers BJ. IGF-I potentiates interleukin2 production in human peripheral blood $\mathrm{T}$ cells. Journal of Endocrinology $1996149351-356$.

12 Pierpaoli W, Baroni C, Fabris N \& Sorkin E. Hormones and immunological capacity. II. Reconstitution of antibody production in hormonally deficient mice by somatotropic hormone, thyrotropic hormone and thyroxin. Immunology 196916 217-230.

13 Bozzola M, De Amici M, Zecca M, Schimpff RM \& Rapaport R. Modulating effect of human growth hormone on tumour necrosis factor- $\alpha$ and interleukin-1 $\beta$. European Journal of Endocrinology $1998139640-643$.

14 Casanova S, Repellin A \& Schimpff RM. Production of interleukin-1 and interleukin-2 by mononuclear cells from children with growth delay in relation to the degree of growth hormone deficiency: effects of substitutive treatment. Hormone Research $199034209-214$.

15 Serri O, St-Jacques P, Sartippour M \& Renier G. Alterations of monocyte function in patients with growth hormone deficiency: effect of substitutive GH therapy. Journal of Clinical Endocrinology and Metabolism $1999 \mathbf{8 4} 58-63$.

16 Michalacos S, Karachaliou F, Vlachoopapadopoulou E, Fotinou A $\&$ Konstandellou E. Tumor necrosis factor- $\alpha$ levels in short children. Journal of Pediatric Endocrinology and Metabolism 200215 193-196.

17 Kooijman R, Willems M, De Haas CJ, Rijkers GT, Schuurmans AL, Van Buul-Offers SC, Heijnen CJ \& Zegers BJ. Expression of type I insulin-like growth factor receptors on human peripheral blood mononuclear cells. Endocrinology 1992131 2244-2250.

18 Stuart CA, Meehan RT, Neale LS, Cintro NM \& Furlanetto RW. Insulin-like growth factor-I binds selectively to human peripheral blood monocytes and B lymphocytes. Journal of Clinical Endocrinology and Metabolism 199172 1117-1122.

19 Baxter JB, Blalock JE \& Weigent DA. Characterization of immunoreactive insulin-like growth factor I from leukocytes and its regulation by growth hormone. Endocrinology $1991 \quad 129$ $1727-1734$.

20 Clark R, Strasser J, McCabe S, Robbins K \& Jardieu P. Insulin-like growth factor-I stimulation of lymphopoiesis. Journal of Clinical Investigation $1993 \mathbf{9 2 2} 540-548$.

Received 5 May 2003

Accepted 15 July 2003 